\author{
https://doi.org/10.52449/1857-4114.2020.35-1.09
}

CZU: 797.2:796.015.3

\title{
ANALYSIS OF TRAINING PROGRAMS OF THE PERFORMANCE SWIMMERS WITHIN THE BASIC MACROCYCLE OF THE ANNUAL TRAINING CYCLE
}

\author{
Solonenco Grigore ${ }^{1}$ \\ Stepanova Natalia ${ }^{2}$ \\ Onoi Mihail ${ }^{3}$, ORCID: 0000-0002-7879-3245 \\ Dorgan Viorel ${ }^{4}$, ORCID: 0000-0002-4649-4734 \\ ${ }^{1,2,3,4}$ State University of Physical Culture and Sports, Chișinău, Republic of Moldova
}

\begin{abstract}
Throughout this research, it has been pursued the process of studying and creating training programs of the performance swimmers during the basic macrocycle of the annual training cycle, where the emphasis was placed on the development of certain characteristics, which had led the swimmers to the greatest results at the most important competitions. The planning consisted of a periodization of the preparation stages and sub-stages known as macrocycles, mesocycles and microcycles. Within the training of the swimmers during the macrocycle, different training methods were used: force, power, mobility, endurance, speed, technique exercises, starts and turns, rhythm training, training for the competition tactic, psychological training. All the training methods listed above should be included in the content of all stages of preparation, with a different emphasis, depending on the training period. During the general resistance period of the macrocycle, the emphasis was put on improving the overall aerobic capacity, strength, mobility, strokes technique, starts and turns, and on improving the resistance to psychological stress. The trainings during this period were mainly composed of technical exercises, swimming with emphasis on arms and legs at a basic resistance intensity. The exercises on mobility were performed daily, focusing on the ankle, back and shoulder joints. Within the specific resistance period maximum values were reached. During the mentioned period, a large part of the resistance training was performed with the basic stroke, about 55-65\%. Regarding training on the ground, the emphasis was placed on rapid repetitions in order to develop muscle strength, and the exercises on mobility were continued. During the competition period the most important competitions were scheduled, the focus of the training, being passed from the resistance to the sprint for all the swimmers, except the stayers. The narrowing period or the final period was planned from seven three-day microcycles, representing a period with a low volume and intensity. During this period, the swimmers competed in various international competitions in order to fulfill the scales of participation in the Olympic Games (Tokyo-2020).
\end{abstract}

Keywords: macrocycle, mesocycle, microcycle, force, endurance, speed, performance swimmers, training programs.

The actuality. The purpose of this paper is to study and elaborate the main theoreticalmethodical aspects with a focus on improving the sports training during the macrocycle for performance swimmers. The training planning within the macrocycle has been studied from the methodological-scientific point of view by a lot of specialists practitioners and theoreticians [3, 6, 8, 9], who present elaborations regarding the volume and 
intensity of the training efforts applied in the training of the performance swimmers.

In order to organize the trainings, in this period it is necessary to have a continuous and uninterrupted increase of the workloads, from the training period to the competitive one. The number of trainings provided in a macrocycle is sufficient to give a concrete idea about the amount and time worked.

Macrocycles are cycles that encompass many mesocycles. In all cases, they have a final objective, which can be represented, either by a period of preparation as a whole or by a complete training cycle, in which different phases of the sport's form are elaborated. The duration of a macrocycle can be extended from three or four months to one year.

In the traditional preparation, there are three fundamental periods:

- the preparatory period, dedicated to the elaboration of the sport's form;

- the competitive period;

- the transition period.

L. P. Matveev [8] suggests the following procedure for the extending of the preparatory period:

- the formation mesocycle;

- the basic mesocycle (general training, development);

- the basic mesocycle (stabilization);

- the basic mesocycle (specific training, development);

- the control and training mesocycle;

- the basic mesocycle (pre-competitive).

The structure of the microcycles is given by the order of the different training units, which are organized according to the objectives and tasks of the mesocycle.

Different types of microcycles can be distinguished, but there is no a general satisfactory classification system for the purposes. The classification of microcycles can be made, taking into account the following factors:

- the ratio between the main exercises and the competition exercises;
- situating the macrocycles in the dynamics of the chosen load;

- the ratio between the volume and the intensity of the load $[1,9]$.

The research hypothesis. It is assumed that by developing and implementing training programs for performance swimmers within the basic macrocycle of the annual cycle, it will be contributed to improving the results of the athletes, in order to fulfill the standards for participation in the Olympic Games (Tokyo2020).

The purpose of the research consists in the improvement and scientific argumentation of the distribution of the material within the basic macrocycle programs of the annual cycle, in order to obtain a maximum effect from the training and to improve the results of the swimmers pursuing the fulfillment of the standards for participation in the Olympic Games (Tokyo-2020).

\section{Research objectives:}

1. Analysis of the specialized literature, regarding the problems of training of the swimmers of higher performance within the basic macrocycle of the annual cycle.

2. Development of training programs of performance swimmers within the basic macrocycle of the annual cycle.

3. Implementation of training programs of performance swimmers of higher by participating in different international competitions in order fulfill the standards for participation in the Olympic Games (Tokyo2020).

Research organization. The experimental study was extended during the period from $11 / 11 / 2019$ to $29 / 02 / 2020$ of a macrocycle, being divided into five mesocycles. Particular attention was paid to the training of swimmers during the basic and pre-competitive mesocycles, which were structured from 7 microcycles of 3 days each. In order to obtain the maximum effect from the training process and to improve the results of the swimmers, the SUPCS Department of Swimming and Tourism together with the Swimming 
Federation of the Republic of Moldova have developed a training program for performance swimmers within the basic macrocycle of the annual cycle.

During this period, training camps were organized for swimmers in Tiraspol, Chisinau, Baku, Bucharest. According to the training plan, the swimmers participated in the following international competitions:

$03 / 12 / 2019$ - 07/12/2019 - The European Championship, Glasgow (Great Britain);

$>$ 29/01/2020 - 30/01/2020 -

International Tournament, Strasbourg (France);

21/02/2020 - 22/02/2020 - Alytus

(Lithuania);

27/02/2020 - 29/02/2020 - Open

championship of the Republic of Moldova.

The Masters of Sport of International Class participated in these competitions: Anastasia Basisto, Nichita Bortnicov, Tatiana Chisca, Constantin Malachi, Tatiana Salcuțan, Alexei Sancov, Dan Siminel. Within the Open Championship of the Republic of Moldova, IMS Chișca Tatiana and Siminel Dan obtained the cups according to FINA points.

Honored coaches of the Republic of Moldova were involved in the training of the swimmers: Eugen Carabețchii, Sergiu Postica, Valentina Semiruncic. The planning of the training programs within the basic macrocycle of the annual cycle had a precise elaboration of the learning and performance objectives, as well as the means, methods and forms of organization appropriate to the proposed objectives.

Training plans for swimmers synthesize the programmed decision system, while ensuring the continuity of training and its optimal rhythm, volume and intensity of effort, duration of breaks, area of energy changes, forms of evaluation. The training plans in the basic macrocycle presented a detailed elaboration of the performance objectives, of the competitive calendar, of the methods and means used, of the requests in the training in micro and mesostructures. In the vision of training and scheduling of training, over time intervals were analyzed and compared, acquiring new and efficient solutions (Table 1).

The planning in the basic macrocycle had specific tasks - the training of the anaerobic threshold, the emphasis was placed on intervals with short breaks and on over long distances in order to increase the general resistance required by any competition test "quality".

The types of requirements that were used in the macrocycle:

- great physical effort (speed, strength, endurance, accuracy, anaerobic effort, aerobic effort, combined and mixed effort: force-speed, etc.);

- great mental effort (involvement of informational, cognitive, decision-making, affective, volitional, motivational, selfregulation subsystems).

In this planning, microcycles represented one of the fundamental units of the training for swimmers. The actual structure of the microcycles was organized according to the objectives and tasks of the mesocycle. The classification of the microcycles was made, taking into account the following factors:

- the ratio between the main exercises and the competition exercises;

- the microcycles positioning in the dynamics of the selected load;

- the number of main goals that must be achieved;

- the ratio between the volume and the intensity of the load.

The microstructure of training during this period, in terms of recovery, was carried out in three phases:

- homeostatic rebalancing of the requested functions;

- development of physiological overcompensation;

- developing of a new level of training [2, $6]$.

The training of the swimmers during this period required two categories of training: 
1. Resistance training in order to improve aerobic metabolism;
2. Resistance training in order to improve anaerobic metabolism and strength.

Table nr. 1. The training program of the swimmers, which were planned in the phase of concentration of the large loads within the basic mesocycle

\begin{tabular}{|c|c|}
\hline ay & 0 \\
\hline 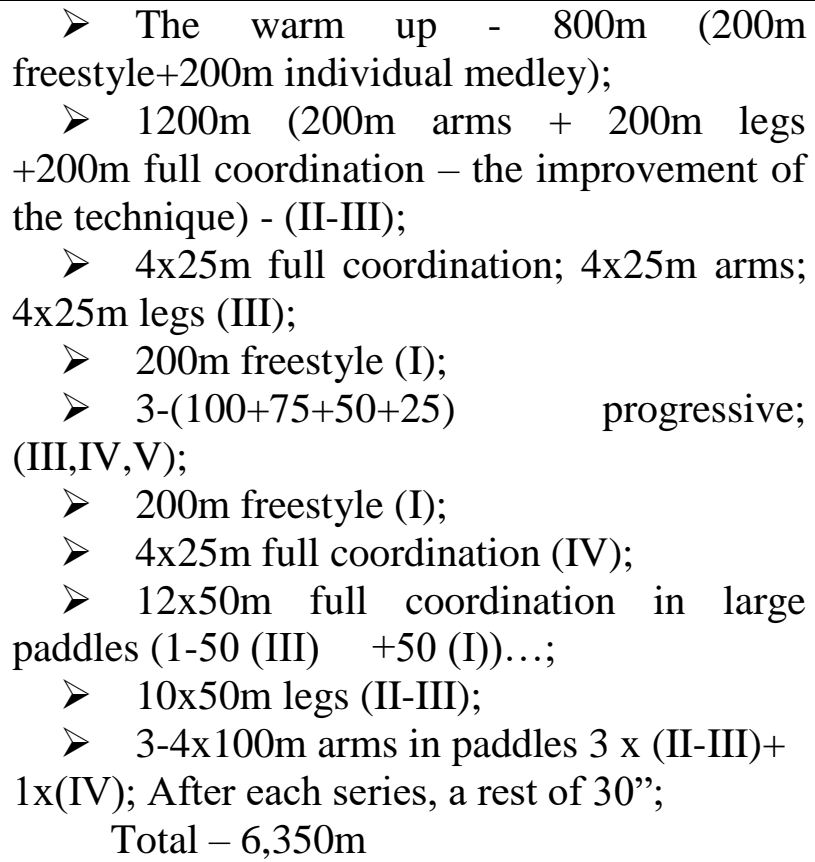 & 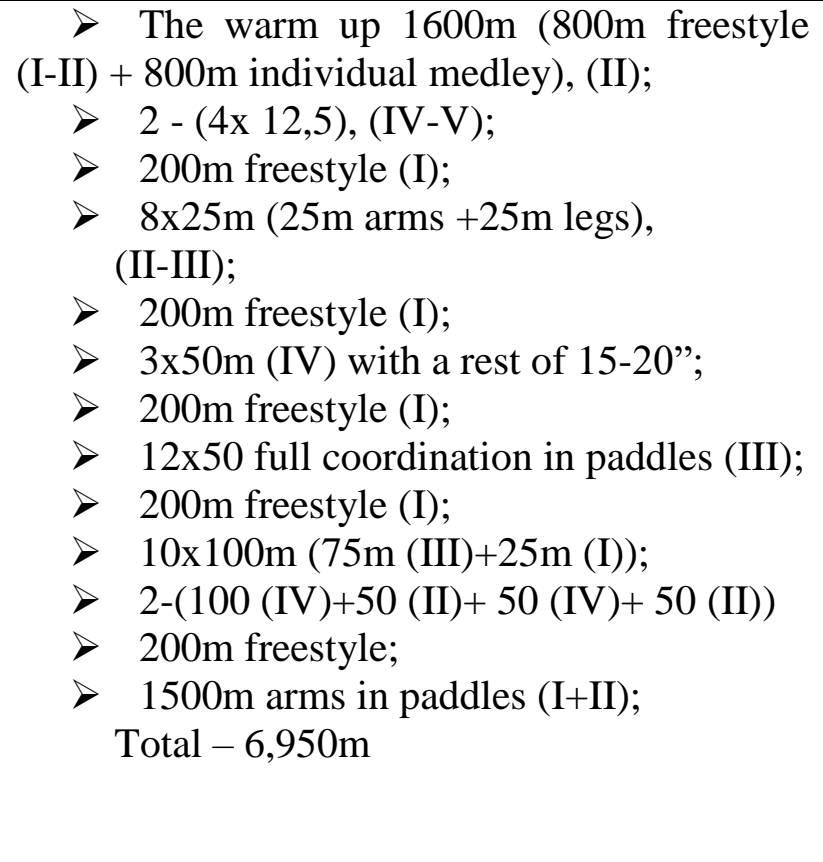 \\
\hline
\end{tabular}

In order to improve the aerobic capacity, the coaches conducted trainings with intensities corresponding to the anaerobic threshold, which led to a significant improvement of the results of the swimmers. In the training of the swimmers were also used three levels of training, which are called resistance, basic and resistance with overload trainings:

1. endurance -1 (basic resistance training);

2. endurance -2 (threshold resistance training);

3. endurance -3 (resistance training with overload).

Also during this period, the coaches performed three types of sprint training:

1. Training with lactate tolerance (sprint$1)$.
2. Lactate production training (sprint-2) in order to increase anaerobic metabolism;

3. Power training (sprint-3) in order to increase the volume of muscle power, which swimmers can transfer to the water [1,9].

Within the preparation of the swimmers, coaches used the following training methods: speed, strength and rhythm training, resistance and power training, training for the development of tactical qualities, interval training, psychological training.

Also during this period, the coaches used sprint training, which had two main purposes:

1. To increase the swimming speed, so that swimmers could "leave" quickly at the beginning of the race;

2. To improve the necessary capacity of the swimmers in maintaining the swimming speed by retaining the accumulations of lactate acid. 
The most trainable mechanisms that improved swimming speed were: 1 - traction technique; 2 - muscle strength; 3 - anaerobic metabolism.

The coaches used a series of exercises in order to improve the traction force, the sense of water during the distance in the anaerobic area. In the concentration phase of the large loads within the basic mesocycle, the coaches paid attention to the special physical training (Tables 2 and 3).

Table 2. Planning of the basic parameters of training efforts in the 21-day precompetitive mesocycle ( 7 microcycles of 3 days) for the performance swimmers

\begin{tabular}{|l|c|c|}
\hline \multicolumn{1}{|c|}{ Load parameters } & $\begin{array}{c}\text { The first stage of the } \\
\text { mesocycle }\end{array}$ & $\begin{array}{c}\text { The second stage of } \\
\text { the mesocycle }\end{array}$ \\
\hline Total volume of work, hours & $36-44$ & $32-35$ \\
\hline The volume of work per day, hours & $3-4$ & $25-300$ \\
\hline The volume of work on land, hours & $2,5-3,00$ & $2,0-3,00$ \\
\hline The swimming volume per day, km & $7-8$ & $6-7$ \\
\hline The swimming volume, km & $80-85$ & $70-75$ \\
\hline The number of trainings per day & 2 & 2 \\
\hline The percentage of effort with different loads & $21-22$ & $23-24$ \\
\hline High & 18 & 20 \\
\hline Significant & 23 & 25 \\
\hline Medium & 29 & 22 \\
\hline Small & \multicolumn{2}{|l}{} \\
\hline
\end{tabular}

In water:

- tensile force in water with elastic tube "Arena": arms, legs, coordination;

- strength skills;

- endurance in the glycolytic - anaerobic zone (test: $4 \times 50 \mathrm{~m}$ with a rest of $10^{\prime}$ );

- endurance in the mixed zone (test: $8 \times 200 \mathrm{~m}$ with a rest of 20-30');

- at the TAE level (the threshold of anaerobic exchange: $8 \times 200 \mathrm{~m}$ ).

On the land:

- ergometer „Swim Trainer”;

- „Mertens Huttel”;

- mobility in the shoulder joints;

- mobility of the spine;

- mobility of the ankle joints [5, 7].

Psychological preparation. The psychological preparation of the athletes was performed by the coaches, and the main objectives of the psychological preparation were summarized at:

- formation and improvement of the sports character;

- development of the features of the sports character;

- strengthening and improving the mechanism of neuropsychological regulation;

- development of levels, which determines the performances;

- the formation of the personal qualities necessary for the swimmers took place due to the modification and the correction of the attitude of the sportsmen towards the completed and the following trainings, his abilities of recovery, the neuropsychic overload, the quality of accomplishing the training tasks, the sport regime $[4,10]$. 
Table 3. Training program in the precompetitive mesocycle for swimmers

(two trainings per day)

\begin{tabular}{|c|c|}
\hline For swimmers of $50-100 \mathrm{~m}$ distance & For swimmers of $200-400 m$ distance \\
\hline $\begin{array}{l}\text { First training of the day } \\
\text { The warm up: } 200 \mathrm{~m} \text { freestyle }+400 \mathrm{~m} \\
\text { individual medley; } \\
4 \times 100 \text { the improvement of the } \\
\text { technique (II-III); } \\
6 \times 100 \text { arms work (II); } \\
4 \times 25 \text { sprint (V); } \\
400 \mathrm{~m}(\mathrm{I}) ; \\
600 \mathrm{~m} \text { arms, legs and full coordination } \\
\text { (II) } \\
\text { Total }-2,700 \mathrm{~m}\end{array}$ & $\begin{array}{l}\text { First training of the day } \\
\text { The warm up: } 200 \mathrm{~m} \text { freestyle }+400 \mathrm{~m} \\
\text { individual medley; } \\
\text { 1000m }(400+300+200+100 \mathrm{~m}),(\mathrm{II}-\mathrm{III}) ; \\
200 \mathrm{~m}(\mathrm{I}) ; \\
12 \times 50 \mathrm{~m} \text { freestyle with a minute rest (III-IV); } \\
400 \mathrm{~m} \text { legs work (II); } \\
8 \times 25 \mathrm{~m} \text { freestyle with a minute rest (IV); } \\
200 \mathrm{~m}(\mathrm{I}) ; \\
2-4 \times 50 \mathrm{~m} \text { freestyle with a rest of } 10 " \text { (III- } \\
\text { IV); } \\
200 \mathrm{~m}(\mathrm{I}) ; \\
\text { Total }-3,800 \mathrm{~m}\end{array}$ \\
\hline $\begin{array}{l}\text { Second training of the day } \\
\text { The warm up: } 800 \mathrm{~m}(400 \mathrm{~m} \text { freestyle } \\
+400 \mathrm{~m} \text { individual medley) (II); } \\
3 \text { - } 4 \text { x 50m(III); } \\
400 \mathrm{~m}(\mathrm{I}) ; \\
6 \times 25 \mathrm{~m} \text { freestyle }(\mathrm{IV}-\mathrm{V}) ; \\
200 \mathrm{~m}(\mathrm{I}) ; \\
1200 \mathrm{~m}: 50 \mathrm{~m}(\mathrm{IV})+50 \mathrm{~m}(\mathrm{I})+\ldots \\
50 \mathrm{~m} \text { from the block start }(\mathrm{V}) \\
\text { Total }-3,400 \mathrm{~m}\end{array}$ & $\begin{array}{l}\text { Second training of the day } \\
\text { The warm up: } 200 \mathrm{~m} \text { freestyle }+400 \mathrm{~m} \\
\text { individual medley; } \\
400 \mathrm{~m} \text { individual medley; } \\
4 \times 100 \mathrm{~m} \text { arms work (II); } \\
200 \mathrm{~m} \text { the improvement of the technique; } \\
10 \times 100 \mathrm{~m} \text { with a rest of one minute and } \\
45 \text { "(III); } \\
200 \mathrm{~m}(\mathrm{I}) \text {; } \\
4 \times 25 \mathrm{~m} \text { freestyle (V); } \\
8 \times 150 \mathrm{~m} \text { with a rest of one minute and } 30 \text { "(II); } \\
200 \mathrm{~m}(\mathrm{I}) \\
\text { Total }-3,700 \mathrm{~m}\end{array}$ \\
\hline
\end{tabular}

Conclusions. In the performed research, the following aspects can be noted:

1. The present paper showed that the theoretical-methodical aspects of the training, applied in the preparation of the performance swimmers, were the basis of the elaboration of a training planning model within the basic macrocycle of the annual cycle, which was implemented within the framework of the fulfillment of the standards for participation in the Olympic Games (Tokyo - 2020);

2. The importance of the swimmer's accomplishment of the programs during this period, led to an improvement of the sports form, which highlighted three characteristic aspects:

- the technical-tactical aspect;

- the organic-muscular aspect;

- the psychological aspect, which concerns the personality traits;

3. The trainings of the swimmers at the end of the basic macrocycle demonstrated the specific organization that pursues reaching of the objectives set;

4. Participating in different international competitions, the international masters of sport 
Chișca Tatiana, Salcuțan Tatiana, Sancov Alexei fulfilled the scales of participation in the Olympic Games (Tokyo - 2020).

IMS Chișca Tatiana became the semifinalist (12th place out of 56 participants) of the European Championship in England (Glasgow), held between 03-07/12/19, at the distance of $50 \mathrm{~m}$ breaststroke with the result 30.57, thus setting a new record of the Republic of Moldova.

IMS Siminel Dan won the gold medal in the $100 \mathrm{~m}$ freestyle and took the second place in the $50 \mathrm{~m}$ freestyle at the International Tournament in Strasbourg (France), which was held from 29/01/2020 to 30/01/2020.

IMS Salcuțan Tatiana won the gold medals at distances $50 \mathrm{~m}, 100 \mathrm{~m}$ and $200 \mathrm{~m}$ backstroke; Basisto Anastasia obtained the gold medal at the distance $50 \mathrm{~m}$ breaststroke (youth) and 2nd place (mature) at the distance $100 \mathrm{~m}$ breaststroke in the Open Championship of Alitus (Lithuania - 21/02/2020 22/02/2020).

\section{References:}

1. Maglischo E. (2000). Să înotăm chiar și mai repede. Manual metodic. București, p.32-161.

2. Maglischo E. (1992). Să înotăm mai repede. Vol. I și II. București: MTS-CCPS, p.145-219.

3. Manno R. (2000). Bazele teoretice ale antrenamentul sportiv. În: Sportul de performanță, nr. 371-374. București: CCPS, p. 41-126.

4. Rîşneac B., Solonenco G., Diacenco E., Stepanova N. (2018). Inotul. Ghid metodic pentru școlile sportive de specialitate. Chişinău: Totex-Lux. 136 p.

5. Rîşneac B., Solonenco G. (2014). Inotul sportiv: Concepte metodologice. Chişinău: Totex-Lux. $291 \mathrm{p}$.

6. Rîşneac B., Solonenco G. (2017). Metodica instruirii şi antrenamentului în nataţie. Chişinău: Totex-Lux. 223 p.

7. Rîşneac B., Solonenco G. (2013). Orientări metodice în pregătirea înotătorilor de performanţă. Chişinău: Totex-Lux. 159 p.

8. Матвеев Л.П. (1997). Общая теория спорта. Москва: Физкультура и спорт, с.138-158.

9. Платонов В.Н. (2012). Спортивное плавание. Путь к успеху. Книга 1 и 2. Москва: Советский спорт, с.278-408.

10. Уилмор Дж. Х., Костилл Д. Л. (1997). Физиология спорта и двигательной активности. Киев: Олимпийская литература. 503 с. 